\title{
A missiological glance at South African Black theology
}

Author:

Kalemba Mwambazambi ${ }^{1}$

\section{Affiliation:}

${ }^{1}$ Department of

Development Studies,

University of South Africa,

Pretoria, South Africa

\section{Correspondence to:}

Kalemba Mwambazambi

email:

Profkalemba@yahoo.fr

Postal address:

PO Box 3037, Pretoria 0001,

South Africa

\section{Keywords:}

Apartheid; Black theology;

Christian mission;

liberation; South Africa

\section{Dates:}

Received: 07 Oct. 2009

Accepted: 10 Sept. 2010

Published: 11 Nov. 2010

How to cite this article: Mwambazambi, K., 2010,

'A missiological glance at South African Black theology', Verbum et Ecclesia 31(1), Art. \#53, 7 pages. DOI: 10.4102/ve.v31i1.53

\section{This article is available} at:

http://www.ve.org.za
(C) 2010. The Authors. Licensee: OpenJournals Publishing. This work is licensed under the Creative Commons Attribution License

\section{ABSTRACT}

Black South African theologians created South African Black theology during the late 1960s and early 1970s as a conscious and theological dimension of the liberation struggle against apartheid. They drew inspiration from African-American theology, biblical hermeneutics and the raw material of their own experiences and suffering, whilst simultaneously creating a new theological paradigm and political orientation to liberate Black South Africans from apartheid and European domination. Inevitably, South African Black theology was a liberation theology aimed at helping to eradicate the existing socio-political order. This article gave a missiological overview of Black theology and examined and assessed the relevance of this theology to contemporary postapartheid South Africa. The critical-theological research method was used.

\section{INTRODUCTION}

The research question is whether South African Black theology continues to have relevance in the postapartheid context and how it might be contextualised for today's needs.

Historically, Black theology did not originate in South Africa. It developed in the Black culture and Black churches of the United States of America where, for centuries, Black Americans were segregated and marginalised in a White racist society. The influence of this theology extended throughout the Caribbean, all the way to South Africa.

Within African theology, the South African branch was called South African Black theology. In fact, South African Black theology is a logical consequence of the colonially inspired theology of apartheid which, in part, grew out of the religious perspective of white Afrikaners. White Afrikaners represented the majority of Reformed Christians, or Calvinists and they were organised into White Reformed churches. Politically, they were pro-government and they became increasingly ecclesiastically isolated. They could not maintain a meaningful relationship with the World Council of Churches (WCC) or with the World Alliance of Reformed Churches (WARC). The theory and practices of the White supremacist theology of apartheid took its justification from a multiplicity of arguments of a biblical nature.

European domination in South Africa began in 1652 with the arrival of the Dutch settlers at the Cape. They had come to establish a victualling station for trade ships making their way to and from Europe and the Orient. For the next 150 years, the domestic economy of the settlement depended upon the importation and enslavement of Africans from outside the region. Dutch, French and German farmers forcefully displaced the indigenous peoples, the Khoikhoi, the San and the Xhosa, in order to possess the vast tracts of prime farm land 'available' (Mukendi 2005:9). Thus it was that these early years established the master-slave relationships that would render race as an indicator of one's dominant or subject status.

The British took over the region in the early 1800s. During the South African wars of 1880-1902, the settlers in the Transvaal and Orange Free State, known as the Boers or Afrikaners, challenged British imperialism with much ingenuity, but they ultimately lost the war. The policy of exploiting African labour was openly endorsed by the British many years before this point (Simms 2000:177). The selfgoverning Union of South Africa, established in 1910 and made up of the former British colonies and Afrikaner republics, constituted a new state ruled by the White minority and sustained by the exploitation of Black people. Britain eventually granted South Africa full independence as a member of the Commonwealth of Nations in 1931.

This White minority consisted of two rival groups: the Afrikaners and the British immigrants generally referred to as English-speaking South Africans. In 1948, the Afrikaners, who formed the majority of White people, elected into office the Nationalist Party to rule the nation on the basis of the apartheid ideology.

Apartheid was a political system that depended on extensive police power and it aggressively entrenched and enforced the existing segregation between White and Black people. New laws that discriminated against people of colour were passed in order to secure the power and dominance of the Afrikaner government and community. Ironically, the policy of apartheid, or separateness between Black and White, presented the government with a practical conundrum: White people wanted free access to African labour, whilst completely segregating themselves from these very same African people.

Apartheid institutionalised racism between 1948 and 1958 through an intricate body of legislation that separated people according to race. The Population Registration Act of 1950 classified individuals in terms of three primary racial groups: White, Bantu or Black African and Coloured or people of mixed descent. A fourth group, the Asians, which included Indians and Pakistanis, was added later. Apartheid granted political, material and social privilege to White South Africans and ensured that they had a monopoly of political power to maintain that privilege. This system regulated every aspect 
of social life (Simms 2000:178):

- people were identified as 'White' or 'non-White'

- romantic and sexual relationships and marriages between White and non-White people were prohibited

- certain jobs were reserved for White people only

- residential and community facilities such as swimming pools were segregated

- separate educational infrastructure, funding and standards were implemented

- non-White people were denied full economic and political participation in the South African body politic and were essentially disenfranchised.

The establishment of the Bantustans or homelands was a further extension of the idea of separateness and of separate development and led to the traumatic forced removals of Black people to designated and often isolated areas unready for human habitation. Segregation filtered, by law, into public transportation, cinemas, restaurants, hotels, trains and waiting areas. In short, the apartheid system rigorously and minutely controlled the movement of and the mutual contact and relations between Black and White South Africans.

In this destructive atmosphere of prejudice, South African revolutionaries of faith created their own branch of Black theology as a weapon in their struggle against apartheid and as an insurrectionary socio-religious voice in Third World politics.

The Afrikaans community experienced a parallel evolution of its theology and this is explored by Simms (2000), who says that

in the development of this racially based volksteologie (theology for the people), the pragmatist attitude evidenced in the decision of 1857 paved the way for the eventual development of a theology for the volk (people).

(Simms 2000:178)

In substance, Afrikaners lived at the intersection of three identities: they were White, they were of Western descent and they were Christian. As such, they viewed themselves as the heirs and the pioneers of a civilising mission in Southern Africa, something of a chosen people. This view was based on the assumption that they were superior and therefore needed to and were right to remain separate from the Black and Coloured people.

In 2004, Gibellini (2004:540) wrote that '... apartheid is a sin, its justification is a moral and theological parody of the Gospel and the persistent contempt that it translates from the word of God is a heresy'. In the apartheid era, the WARC was deeply concerned about the theological developments in the Reformed churches in South Africa and the damaging role they were playing by providing spiritual and philosophical support to apartheid ideology and, indeed, by implementing apartheid within their congregations. Consequently, the WARC publicly and resolutely condemned the practice of apartheid during its general meeting in Ottawa in 1982.

Into this cauldron of religious conviction that apartheid was simply about protecting the rights of the volk to have their own country and the devastating impact on the dispossessed Black majority of the daily operation of apartheid, there arrived a movement for recovery called the Black Consciousness Movement. As Mukendi (2005) points out, it had its antecedents in the claims and the movements of the 19th century and early 20th century:

South African Black Theology, being one model of 'liberation theology' has its historical roots in the reflection of ordinary Black Christians on their experience of racism and oppression in South Africa. It was more pertinently through student movements that Black Theology as an explicit, articulate and scholarly reflection arose.

(Mukendi 2005:3)
The process of decolonisation taking place in the rest of Africa after the Second World War was at odds with the direction apartheid was taking. A rich array of ideas and powerful Black personas supported decolonisation and freedom and these included Négritude (Léopold Sédar Senghor), African humanism (Kenneth Kaunda), African socialism and African self-sufficiency (Julius Nyerere) and the influential movements born overseas in the Afro-American community, such as the Civil Rights Movement (Martin Luther King) and Black Power (Stokeley Carmichael). These all served to accelerate the pace of change in colonial Africa.

Thus, this brief look at the historical background to Black theology leads us to the emerging perspective on Black theology in the current South African context.

\section{RESEARCH BACKGROUND AND DEVELOPMENT}

Historically, Black theology is a Bible-centred theology that possesses an organisational and philosophical history that spans 80 years, beginning in the late 1800s and reaching maturity in the second half of the 20th century. Over this period, it emerged as a theological critique of the socio-political ramifications of apartheid and argued that the God of the Christian Bible would condemn the system as wicked and command its destruction. Three student organisations were pivotal to the history of Black theology:

- The Student Christian Association (SCA), established in 1896.

- The University Christian Movement (UCM), organised in 1966.

- The South African Students Organisation (SASO), founded in 1968.

Remarkably and unexpectedly, the political and social histories of these three groups demonstrate a gradual shift from liberalism to radicalism and from interracial cooperation to racial separation. Initially, Africans, Coloured people, Afrikaners and English-speaking White people were all members of the SCA. The SCA was a multi-racial organisation committed to the reform of public policy on the native question. The activities of the Fort Hare Conference of 1930 illustrate the SCA's approach to accomplishing social change. Members from the various ethnic groups shared meals at the same tables, competed in the same sports and participated in the same discussion groups (Mukendi 2005:17). This was a deliberate affront to the customs of the day that mandated racial separation. White segregationists challenged this interracial mixing and the Black contingent of the SAC leadership responded that whilst they were committed to equality, they were not seeking forced social contact:

With respect to the social relationship between Black and White in South Africa, we, the Executive and members of the South African Native College Students' Christian Association, wish to state that although we shall always expect and work for social justice for all ... we do not wish to press for any intimate social intercourse between the two races.

(Mukendi 2005:9)

Yet, despite the initial commitment to unity, disruptive tensions existed within the group over apartheid and separate development. Some supported the institution, arguing that it was biblically based, whilst others condemned it as a violation of biblical morality. This ideological controversy grew progressively more intense and divisive and by 1965 the SCA had fallen apart (Mukendi 2005:13). However, two years later, in 1967, 70 students, intent on maintaining multi-racial political discourse and activism, gathered to form the more radical UCM as an anti-apartheid organisation. The multi-ethnic UCM became remarkably and immediately popular. Its membership included White people from as many as 30 English universities and such large numbers of African collegians that they comprised the 
majority of members (Simms 2000:177). By the end of 1968, the government had begun its assault on the organisation as the UCM became increasingly confrontational towards the apartheid system. During this time, White participation declined, whilst Black membership kept increasing and the UCM's politics became progressively more radical.

During the 1970s, SASO was at the vanguard and stimulated antiestablishment activism, provoked African student unrest and mobilised the resistance efforts of the Black community at large. However, most importantly for this discussion, the organisation created an ideological climate that nurtured the development of South African Black theology rooted as it was in its early beginnings in the UCM. Basil Moore was the first president of the UCM and a lecturer in theology at Rhodes University. He initiated serious reflection on the African theology of liberation. Over the next few years, he organised discussion groups and conferences on the topic and studied the writings of James Cone, the African-American who founded Black theology in the USA in 1969. In addition, Moore worked with Ntwasa, an Anglican clergyman, to convene the UCM's South African Black Theology Project and published Essays in Black theology in 1972 (Simms 2000:177). This seminal work, which the government banned soon after its publication, contained 17 essays, written mostly by Black South Africans that dealt with various aspects of Black theology. The UCM was the most radical Christian movement in South Africa and it did a great deal of work during its existence from 1967 until it was disbanded in 1972.

The intellectuals of SASO developed their theology as a counterhegemonic ideology. During the 1970s and 1980s, this theology 'conscientised' Black people and motivated their struggle for freedom. Indeed, this theology challenged the ruling class ideas that claimed to justify the subjugation of Black people, affirmed their human dignity and validated their desire for liberty. In this connection, Moore (1974) suggests the following:

Black Theology needs to explore images of God which are not sickening reflections of the White man's power-mad authoritarianism. We need new images which are freeing images in that they are images of unity and wholeness, images of humanising relationships of love and truth, and justice and kindness and mercy.

(Moore 1974:9)

This brief look at the political history of these three radical student organisations sets the scene for an examination of the ideological substance and revolutionary thrust of Black theology. Significantly, the philosophical development of these three student groups underwent a gradual shift from liberalism to radicalism and from the ideal of interracial cooperation to the understandable move towards Black self-separation. South African Black theology was an anti-ruling class ideology that served as a tool of the liberation struggle against apartheid. Boesak (1977) has this to say:

Black Theology is a situational theology. It is the Black people's attempt to come to terms theologically with their black situation...

It seeks to take seriously the biblical emphasis on the wholeness of life ... trying to transform the compartmentalized theology Blacks have inherited from the western world into a biblical, holistic theology. It is part of the Black struggle toward liberation from religious, economic, psychological, and cultural dependency.

(Boesak 1977:13)

Boesak's definition of Black theology refers to a characteristic transformation of Western theology and the notion of European Christianity as an ideological wellspring. He also refers to the definitive component of the 'Black struggle toward liberation' (Simms 2000:178).

Motlhabi (1974:78) explains that South African Black theology 'involves a reassessment of the traditional Christian message and the role of Christ as the Saviour of Black South Africans'. However, not only did Black theology cite the New Testament as the source of its radical ideas but it looked to the Old Testament as well. In the Exodus narrative, God, the Saviour of Israel, delivered the nation from Egyptian bondage as a demonstration of His sovereign power and love for that nation. Boesak (1977:17) adds, 'God is on the side of the oppressed, the underdog, the down-trodden, and, by analogy, on the side of Blacks fighting against the White power structure.'

According to North American scholars, a theology of liberation was necessarily grounded in the life and history of the Christian church. Inspired by this position, James Cone interpreted the person of Jesus as a Black Liberator who came to emancipate African-Americans from racist oppression. Similarly, through their scholarship and publications, South African scholars and thinkers such as Steve Biko, Alan Boesak, Desmond Tutu, Tinyiko Maluleke and Barney Pityana represent the development and articulation of this particular contextual theology. This has presented theologians and activists in our context with a particular Black Christian missionary self-identity. The Christology of South African Black theology portrays Christ as the Black Redeemer of Africans exploited by European colonisers. Indeed, South African Black theology was a revolt against the enslavement of Black people. This theology sought to affirm the human dignity of the African people and challenged missiology to take into account its social-critical function in dealing with world mission and diaconate and development projects in order to come to liberating missiological praxis (Simms 2000:178).

South African Black theology is as authentic as it is contextual and prophetic and played a great human revolutionary role during apartheid, especially in its central and convincing biblical message that Black liberation was equivalent to the history of God's liberation of Israel. Boesak (1977:42) points out that for Black Christians, Jesus Christ is regarded as the 'Black Messiah' because he identifies with those who are oppressed, forsaken, neglected, rejected or devalued by unjust societies.

Mosala (1990:1) affirms that South African Black theology was born to '[conscientise] the Christian church' for it seemed that the church was responding to apartheid with equanimity. However, certain Western political elements supported the fundamental reproduction of a discriminatory society on the basis of apartheid theology and were complicit with White South African Christians. Consequently, Black theologians stressed the liberation struggle of Black South Africans against racial discrimination and were incontrovertibly reformist. A new religious culture was underway and its political orientation would help to liberate Black South Africans from decades of oppression under apartheid.

Mosala (1990:2) discusses the fact that, historically, Black Christian religious culture was a dependent culture, embedded 'in the middle of the other white' religious culture that had used Christianity to support the 'oppression and the exploitation of the blacks'. This, in part, was the reason why South African Black theology's critique of White South African religious culture and its negative attitude to Black cultures led Black theologians to work towards the cultural autonomy of the Black people.

The idea that one culture might be better than another or that there is some sort of pecking order amongst different cultures did unspeakable damage and now, in our time, in the context of the global village, it is essential to nurture and protect a shared culture of peace and social justice. Boesak (1984:149) sees this lack of love for the other going all the way back to Genesis (4:116) when Cain killed his brother Abel and Maluleke (2005:357) refers to the sacrifices that Steve Biko made for the 'liberation' of Black South Africans in 'Jesus Christ' and, quite simply, out of love of his neighbour (Maluleke 2008:115). It is love of the other that was missing in the theology of apartheid.

A glance at South African Black theology in terms of church doctrine in the apartheid era reveals that Black scholars criticised 
and reinterpreted three pivotal aspects of their received belief system:

- The person of God

- The message of the Gospel

- The humanity of Africans.

Relative to the person of God, they repudiated the image of God as a White man invested with supreme authority and dictating universal affairs, 'the man at the top', for it implied that only White men were made in the image of God. The idea that God was a patriarchal figure that He demanded 'submission' and 'blind devotion to his will', whilst threatening inescapable 'judgment' and punishment for individual self-expression beyond the bounds of conservative Christian morality was rejected. They contended that this notion of God entrenched White male domination and encouraged Africans to consent to their own subjugation (Simms 2000:177). South African Black theologians reinterpreted this image of the deity to support their struggle for liberation. Motlhabi (1974:126) affirms that 'God is neither our servant, to be treated as we choose, nor our master, to treat us as he chooses, but our comrade and friend in the struggle for freedom'. Ntwasa and Moore (1974) state further:

Black theologians have to be iconoclasts of the 'White' God. They have to tear down every image and symbol that, by presenting god as 'White', reinforces this sense of human inferiority and worthlessness [amongst Black people]. This means not only removing 'White god' pictures, but more important, the White men who seem to believe that it is their whiteness that places them closer to God and thus to the source of the truth and ability.

(Ntwasa \& Moore 1974:25)

However, Black theologians, including Buthelezi (1974), unreservedly condemned this approach:

Black Theology challenges established Christianity to engage in a dialogue with the Black people who feel that somehow theology has not taken them into consideration.

(Buthelezi 1974:35)

They cautioned the clergy to cease preaching a 'pie-in-the-sky' type of religion and instead to come down, Christ-like and toil with Black people spiritually and existentially in the sweat and dust of daily life.

In essence, African biblical scholars objected to the West's salvation-of-the-soul theology. They contended that a person's spiritual aspect cannot be separated from his or her political environment: therefore, the salvation of the soul must encompass socio-economic liberation. Consequently, from this perspective, the message of the Gospel involves physical as well as spiritual freedom and immediate as well as eternal benefits. In this connection, Ntwasa and Moore (1974:24) observed that 'Black theologians criticized and reinterpreted not only the dominant notions of God and the gospel, but also ruling-class ideas of African humanity as well'. They charged traditional clergymen with insidiously teaching that Blackness was 'evil, dark, secret and reeking of "witchcraft"', that African religion and culture were 'heathen and immoral' and that the indigenous people were 'inferior, stupid, untrustworthy, cowardly, and cringing'. With these ideas, European ideologues employed theological authority to buttress the racist status quo. However, South African Black theologians confronted this distortion, 'retrieving the image of their blackness from the dung-heap of colour prejudice' (Buthelezi 1975:19). Accordingly, Mpunzi (1974) says:

God affirms my uniqueness, and so my blackness ... you [Black person] must affirm yourself as a human being no matter what your situation or what others may say or do to you ... You must love the sign of your humanity which others treat as the sign of your lack of humanity. You must love your own black body-your blackness.

(Mpunzi 1974:137)

Thus, South African Black ministers preached that God and Scripture validate African personhood and human dignity. Tutu (1974:73) affirms that 'we [as Africans] matter, we are alive and kicking, and black is beautiful'.
The missionaries had created an indigenous church that, according to South African Black theologians, destroyed group solidarity and cultural transmission. Out of respect for group solidarity, traditional Black culture esteemed communitycentredness and values such as joint property ownership, familial interdependence and group decision making. However, the missionaries, as church planters, extinguished this interconnectedness. Possessing the values of an individualistic society, they contextualised the Scriptures and taught Black people that God loved them on an individual basis and held them personally accountable for moral choices. Furthermore, reflecting their capitalist worldview, Western ministers taught their converts to value individual enterprise and self-centred acquisition. Thus, they destroyed what Goba (1974:68) calls 'corporate personality' that is, the African notion that 'I am because we are, and since we are, therefore I am'.

Regarding cultural transmission, the missionaries were similarly destructive. The missionaries taught African children, under the guise of hygiene and good manners, to disrespect and disconnect from their social traditions and tribal customs. Biko (1974:44) notes that 'children and parents saw life differently and the former lost respect for the latter'. The White missionaries developed churches characterised by an individualism that subverted group solidarity and caused intergenerational discord and in this manner, their Gospel disrupted cultural transmission.

However, South African Black theologians reinterpreted this notion of church. Ntwasa and Moore (1974) observe that:

The church was a company of liberators united with Christ-in-hisstruggle-against-human-bondage. To be Christian was to fuse with the Saviour and to share [with him] the quality of being totally engaged in the struggle against evil - against people's bonds.

(Ntwasa \& Moore 1974:114-115)

Consequently, South African Black theologians reinstated the values that the missionaries had destroyed; indeed, they reconstituted the church as a Christian community colabouring with its Redeemer and as such the church deplored individualism and preserved cultural tradition. In terms of their relations with the state, South African Black theologians opposed the government's authoritarianism as expressed, for example, in its Bantustan politics.

Concerning their relations with each other, South African Black theologians stipulated that in their own organisations they would insist on democratic freedom and that the needs of the masses would dictate policy. Concerning their ultimate relations with White people, South African Black scholars determined that after they had 'thrown off the shackles of oppression, they would embrace Europeans as comrades and friends, and not subjugate them as servants' (Simms 2000:178).

In my view, the missiological challenge presented by South African Black theology can lead to a reconstitution of the ideas of the church and to taking up the responsibility of bringing the Gospel to White people to offer them the joy of belonging to a community that is marked by a known and palpable unity in a dynamic 'corporate life', which has the power to break every yoke of human bondage. Maluleke (2002:154) points out that 'the time has come for Black and African theologians to confront some of the basic presuppositions on which they have been built'. To produce a new South Africa, a Christian egalitarian society could be achieved through the Black church and in this new biblical social order, all people would have equal opportunity and the dispensation of privilege based on race would be abolished.

However, Black theologians did not challenge only their contemporaries to become agents of change; they planned ahead to raise a future generation of leaders who would popularise their ideas because African Christianity has the potential for 
making four specific contributions to a cultural revolution:

- a moral standard

- a structured community

- an emancipated language

- a divinely inspired commitment.

This would involve the re-evangelisation of Africa, reconstructing, reconscientising, Christian education, contextualising African theologies, rethinking the Christian mission for African churches, reimagining new ways to realise community development based on biblical hermeneutics, assisting the ongoing struggle against poverty, developing new tools for Christian leadership and searching for a new inclusive language of naming and communication. Addressing the issue of sexual violence, an area where the church is all too silent, it will be necessary to rethink the transformation of communities so that they take cognisance of the rights and dignity of women and of women's theologising in the construction of an authentic African theology. Whilst not denying the power of the cross (Maluleke 2006), South African Black theology has added to the current body of knowledge and one aspect of its continued relevance is that it proposed a new way for the positive transformation of African societies. Today, we can draw inspiration from that new approach in our search for a pastoral or missiological model of care that is contextual and liberating.

South African Black theology has joined other theological schools, especially those of French-speaking African theology and the Black theology of James Cone. It is obvious that South African Black theologians were influenced by such Western theologians as Tillich, Moltmann and Metz (Villa-Vicencio 1994:26). Obviously, South African Black theology focuses on answering the precise problems of South African Black Christians. The sources of African theology in English-speaking Africa are in particular the Bible, the Christian heritage, traditional religions, African anthropology and other experiments and social realities. However, within the framework of African theology, African theologians such as Appiah-Kubi, Bediako, Biko, Boesak, Buthelezi, Kanyora, T.S. Maluluke, Mbiti, Mofokeng, Mosala, Mugambi, Mpuzi, Nolan, Pityna, Oduyoye, Shembe, Tutu, Ushara and others fought for liberation not only from social, economic and political oppression but from any form of oppression. Mugambi (1989:51) affirms that 'Africans can seek leaders who point the way of immediate liberation to them, to release from disease, oppression, hunger, fear and death'. From this point of view, French-speaking African theologians join with English-speaking African theologians to affirm that African theology can be a theology that takes account of the signs of the times.

Theologically, in its current context, Africa needs a theology that raises its voice against all forms of oppression and all forces of darkness at work in the world and in Africa today. However, the theology of African liberation is not only about redressing the injustices of the past but also about theologians reflecting on African values in order to contextualise the message of a dynamic evangelical Christian mission.

Black theology often refers to the Word of God in Genesis (1:26): 'Let us make men with our image ...'. Thus, Boesak (1978:228) states that 'South African Black Theology is a theology of the liberation of the Blacks in the light of the revelation of God as a Jesus Christ'. South African Black theology analyses the living conditions of Black people in such a way that the Black community can understand that the development of a Black humanity is in conformity with the Gospel. According to Baartman (1978:157), 'It is a theology which seeks to interpret the action of God starting from the experience of the black people'. However, South African Black theology is characterised by some major theological orientations: negation, assertion and liberation.

\section{A theology of negation}

A missiological overview of South African Black theology demonstrates that the first characteristic of this theology is its negation. This negation denounces the prolonged nuptials of the civil capacity and the religious capacity within the framework of South Africa. The reputations of some churches have been blemished by their support of racist ideology and South African Black theology has denounced those who served the cultural and political interests of the oppressors and closed their eyes to the suffering of the oppressed.

Unfortunately, some South African Black theologians who criticised Western theology and the theology of apartheid that was founded by sections of the White South African Christian community today support discrimination against non-South African Black, Coloured and White people. Some Black scholars are using the same concepts with which Black theology condemned apartheid to support social injustice under the Black government.

I think that South African Black theology is called to adapt to current African realities and to justify the positive transformation of Africa. As the world changes, it is important that Black theology too change its old method of struggle by contextualising its design and vision. So South African theologians need to change their mentality for it is important to harness theologians and missiologists to research how best to contextualise the Christian mission in Africa and in African cultures. African theologians and intellectuals need to ethically observe and include the norms of reconciliation as part of the fulfillment of their world mission. Obviously, without this continental awakening and missiological research into those elements that will make comprehension of the Gospel a factor in the positive transformation of postcolonial Africa, Africa will not progress in its contextualisation of the Gospel. Its vision will need to encompass the African Renaissance, the great desire and need for reconstruction and the relationship between spiritual and physical liberation to be truly African.

Current missiological debates on South African Black theology suggest, in my view, that African theologians can promote peace, justice, reconciliation, reconstruction, renaissance, truth, collaboration, consideration of the other and the defence of the poor and the oppressed because God supports them. Obviously, the African churches with their various forms of theology do not exist entirely independently but exist to announce the Good News in Africa. However, this Good News will not have any relevance in African eyes if it is not an essential and accessible part of their lives. In other words, an African theology, whatever its form that does not promote the total spiritual and physical liberation and well-being of the African people and the unity of Africa is not likely to succeed. Moreover, South African Black theology could greatly stimulate the true democratisation of African countries in the Christian cause of the dignity of each person, the love of God and the love of the other. Any Christian mission in Africa cannot afford to neglect the issue of cultural identity. Maluleke (1997:324) proposes a deeper theological analysis of the aforementioned political developments and, more specifically, the role of nation building, the South African Truth and Reconciliation Commission and the other broader truth and reconciliation processes, relating these processes to silencing of the voices of the poor and oppressed.

\section{A theology of affirmation}

The starting point is therefore to deal with the South African historical legacy and how the subsequent fundamental sociopolitical transformations impact all aspects of the lives of South African people. In fact, this historical pattern has to be understood if there are to be solutions to the malaise expressed in current theological debates. South African Black theology is also a theology of affirmation in spite of its double negation because of its persuasive affirmation of Black existence. On this subject, Kesteloot (1967) notes the following: 
In proclaiming the movement of Negro rebirth, Blacks affirm that we, creators of the new Negro generation, want to express our Black personality unashamedly and fearlessly. If that is to the liking of the Whites, we are extremely happy. If not, it does not matter. We are beautiful and ugly too. The tom-tom cries and the tom-tom laughs. If it is to the liking of Coloured persons, we are happy. If not, it does not matter. It is for tomorrow that we will build the solid temples we know how to build, and we are drawn to the top of the mountain, free in ourselves.

(Kesteloot 1967:21)

Ndjate (1984:102) writes that 'we exist; God himself confirms our existence'. South African Black theology is an affirmative theology because it affirms with courage and force the importance of a displaced and dispossessed people to the God of the oppressed. This theology is imposed, like the assertion of Négritude, on the theological register: the Black person exists because God supports his or her existence. Ndjate (1984:102) contends that 'this worship always refers to freedom under the reign of God'. Consequently, this worship is not separated from life. It is in the fight against racism and oppression that the Black church creates and recreates its theological comprehension of the faith and gives voice to cries of praise and songs about the fight for the liberation of the oppressed. Obviously, South African Black theology can play a big role in the transformation of society because it originated in the context of the fight against apartheid, which is somewhat different from today's context, with the shift in political power back to the majority.

Consequently, this theology can take into account the reality of the moment and transform itself to meet the needs of the current South African context. This theology is sometimes defended and supported by certain Black theologians and Coloured and White South Africans. In fact, it is also a theology of liberation that fought and can continue to fight for the total emancipation of the African, Black, Coloured and White peoples in accordance with the supreme order of Christ who stipulates the following in Luke (4:18-19):

The Spirit of God is on me, because it appoints me to announce the Good News to the poor; it sent to me to cure those which are broken hearted, to proclaim delivery to prisoners, and sight to the blind, to free the oppressed, to publish one year of the grace of God.

It is one of the missions of Black, Coloured and White South African theologians to liberate the African people. Unfortunately, writes Buthelezi (1975), the majority of 'Black Christian South Africans, as a distinct grouping, did not contribute a significant enough share to the evangelization of South Africa, apart from the people of their own race'. This reduced role in the evangelisation of South Africa is understandable, but in the current African context, I think it is missiologically necessary to conscientise Africa in general and South Africa in particular to a contextualised Gospel of Jesus Christ, the Black Messiah during apartheid and to avoid any new forms of apartheid between African theologians and other African: White or Coloured communities or peoples. Currently, the political, economic, missiologic, ecclesiastical and social realities of South Africa all bear the transformation message. Maluleke (1997:339) states that the answer will be informed by the quests and struggles of people for political, economic, cultural, spiritual and ecclesial self-determination'. Social transformation signifies a fundamental change in the nature of the relations within institutions in society. This significant fundamental transformation touches on institutions, strategic norms and values and it can affect individuals, churches, organisations and whole societies. But this transformation means very little if it proceeds without Christ (Simms 2000:177).

\section{A theology of liberation}

This theology was born during the apartheid era and it is integrated with the experience of the oppressed Black South African. However, one of the most remarkable differences between South African Black theology and that of the United States, for example, resides in the situation in which each one developed. Obviously, South African Black theology did not have the character of an idealistic disincarnated African theology because it was a cry of the deepest suffering; sometimes it resembled a cry of revenge for a better future. However, South African Black theology is a 'theology of liberation' (Boesak 1978:256). Its intentions and its methods joined those not only of French-speaking African theology but also of the Latin American theology of liberation. Obviously, South African Black people do not consider only the hand of God within the framework of personal safety but it also considers social, economic, religious, cultural and political delivery, as underlined by Dembo (22005)

because God is made known in the history of Israel oppressed, and in the decisive way Jesus Christ spoke of the oppressed, it is impossible to speak about God without seeing his hand in the contemporary release of all oppressed.

(Dembo 2005:26-27)

It is necessary that African theology in a world of globalisation confess the liberating activity of God the Almighty on the side of the oppressed; that is to say, to be an African Christian is to identify with the struggle of the slaves and of the oppressed and to believe that God will come to their aid.

South African Black theology endorses the particular characteristics of any theology of liberation. Maluleke (2008:115116) explains that 'it does not act of two fields, but only one life aspired by God the liberator who spreads himself in the church as He is spread in everyday life'. However, some concepts can be revised to accommodate the current post-apartheid context and the orientations of the South African independent churches, which have undergone a radical change since apartheid was dismantled. However, South African Black theology gives the independent African churches a privileged place in Black theology, as Ndjate (1984) affirms:

Victor Mayatula, of Bantu Bethlehem Christian Apostolic Church of South Africa, is among those which expressed with more strength the bond between Black Theology and the independent African churches: like other works out a speech of liberation of the colonial situation.

(Ndjate 1984:103)

South African Black people are a 'people-sign', a 'peoplewitness', for all the African countries. Their word, born from identification with the 'unhappy servant' (Isaiah 53:4), challenges all Black Christian communities and confronts them with the word of the 'assassinated servant'. God, in Christ, is present at any human liberation, today as yesterday. But this message can be discovered only at the centre of an oppressive situation. Obviously, the defenders of the various theologies of the independent South African churches point out that it is difficult to be Christian or to be for Christ when one is oppressed and regarded as a slave. So solidarity with Christ necessarily passes in the current context as racial compromise. However, the dialogue of confrontation amongst diverse cultures brings into play the historical and theological situation of the African Church. Mukendi (2005) says that

the church indeed, is driven by history... It can seek how to expose the truths of the faith to different times and to different cultures, how to adapt its action to the changes which operate in the world.

(Mukendi 2005:107)

It is possible to distract the African people with false visions and false prophecies in the name of African messianism and Kritzinger (1988) says that 'within the new South Africa the dawn of the new interfaith, multifaith and multireligious initiatives' is detectable. Hence the necessity and the opportunity to revitalise the Christian mission and the value of the re-evangelisation of Africa for African reconstruction, African stability and African transformation whilst at the same time preserving and respecting the value of African culture in the postcolonial context. Motlhabi and Mokgethi (2008) add that we need

to explore possible ways of making the Eucharistic celebration more meaningful in Africa. The reason for this concern is that the Eucharist is the 'source and summit' of the Christian life.

(Motlhabi \& Mokgethi 2008) 
This includes symbolic gestures, local languages, proverbs, enthronement, local staple food, invocation of ancestors and others. Missiologically, it is hoped that now there is African political leadership, the theological errors made by the White missionaries due to their ignorance of African religious beliefs and practices, philosophy, customs, culture and language and the harm done by colonisation will be erased and African theology will be Africanised in such a meaningful way that Africans will be able to identify themselves with the Gospel of Jesus Christ. The foreign garment in which the Gospel was wrapped (i.e. Western culture) is a garment that needs alteration before it can be put on.

\section{CONCLUSION}

This article has given an overview of South African Black theology, which developed in reaction to the theology of Englishspeaking Africa and enculturation with French-speaking Africa. Even today, after the decline of overt colonialism, Africa experiences the after-effects of colonialism in the form of economic dependence, cultural alienation and the exploitation of the continent's rich natural resources and large labour force by global interests. This sometimes occurs with the complicity of some African elites and churches. For this reason, African theologians seek to reach those furthest from privilege and to take up the new method of in-depth evangelisation for a positive transformation and liberation of the people.

It is because of the liberation of Africa that the majority of African theologians fought theologically and continue to fight through various African theologies to emancipate the African people completely. The African Renaissance and regional integration remain the only hope for English-, French- and Portuguesespeaking Africa because, in spite of political independence, the majority of African countries still remain largely dependent on international assistance and multinational companies; dependence on the West (i.e. economic, social, political and cultural dependence) lingers. Moreover, Madagascar and even Mauritius remain alienated culturally, dependent and under foreign control. However, South African theologians did not generally embrace liberation in their theologies in the same way as French-speaking African peoples because the majority of South African theologians chose to go their own way. Moreover, they adopted in their theologies the more empirical and less speculative approach, although they shared with the French-speaking African peoples the same fundamental goal of re-evaluating African traditional thought, culture and religion. However, the majority of African theologians fought not only for socio-economic and political liberation but also against any form of oppression. Indeed, the fight of South African Christians against apartheid was a brave one, based upon theory that was formulated little by little and this South African Black theology sought to answer the precise problems of the South African Black Christian. Unfortunately, some South African Black theologians are today responsible for instigating the very types of political and ethnic discrimination that they condemned under apartheid. New developments in the debate on missionary ecclesiology make this an exciting new era for missiology, especially in the South or Third World. Unless the impulses of this important new era are caught up in a total revision of what has hitherto been considered the adequate structures of South African Black theology, we will have missed a very important opportunity to uplift the African continent as a whole.

\section{REFERENCES}

Baartman, E.N., 1978, 'La conscience noire: ce qu'elle représente pour l'église' [Black consciousness: What it means for the church], in A, Goquel and P, Buis, Chrétiens d'Afrique du Sud face à l'apartheid, p. 291, L'Harmattan, Paris.

Biko, S., 1974, 'Black consciousness and the quest for a true humanity', in B. Moore (ed.), The challenge of Black theology, pp. 36-47, John Knox, Atlanta.
Boesak, A.A., 1977, Farewell to innocence, Orbis, Maryknoll/New York.

Boesak, A.A., 1978, Black theology and Black power, Mowbray, Oxford.

Boesak, A.A., 1984, Black and reformed: Apartheid, liberation and the Calvinist tradition, Orbis, New York.

Buthelezi, M., 1974, 'An African theology or Black theology', in B. Moore (ed.), The challenge of Black theology, pp. 29-35, John Knox, Atlanta.

Buthelezi, M., 1975, 'The Christian challenge of Black theology', in P, Moore, Black Renaissance, p. 156, John Knox, Atlanta.

Cone, J., 1975, God of the oppressed, Harper \& Row, San Francisco.

Dembo, T., 2005, Mission de la théologie africaine [Mission of African theology], Mission MED, Kinshasa.

Gibellini, R., 2004, Panorama de la théologie au XXe siècle [Panorama of theology in the 20th century], Cerf, Paris.

Goba, B., 1974, 'Corporate personality: Ancient Israel and Africa', in B. Moore (ed.), The challenge of Black theology, pp. 65-73, John Knox, Atlanta.

Kesteloot, L., 1967, Anthropologie négro-africaine [Black African anthropology], Gerard et Co., Verviers.

Kritzinger, J.N.J., 1988, 'Black theology: Challenge to mission', DTh thesis, Department of Missiology, University of South Africa.

Maluleke, T.S., 1997, 'The smoke-screens called Black and African theologies: The challenge of African women's theology', Journal of Constructive Theology 3(2), 210-219.

Maluleke, T.S., 2002, 'Identity and integrity in African theology: A critical analysis', Religion and Theology, April, 26-41.

Maluleke, T.S., 2005, 'The next phase in the vernacular Bible discourse: Echoes from Hammanskraal', Missionalia 32(2), 355-374.

Maluleke, T.S., 2006, 'The Africanization of theological education: Does theological education equip you to help your sister?', in E. Antonio (ed.), Inculturation and postcolonial discourse in African theology, pp. 61-76, Peter Lang, New York.

Maluleke, T.S., 2008, 'May the Black God stand please!: Biko's challenge to religion', in A. Mngxitama, A. Alexander \& N.C. Gibson (eds.), Biko lives!: Contesting the legacies of Steve Biko, pp. 115-126, Palgrave Macmillan, New York.

Moore, B., 1974, The challenge of black theology in South Africa, John Knox, Atlanta.

Mosala, I.J., 1990, Biblical hermeneutics and black theology in South Africa, Eerdmans, Michigan.

Motlhabi, M., 1974, 'Black theology and authority', in B. Moore (ed.), The challenge of Black theology, pp. 119-129, John Knox, Atlanta.

Motlhabi, M. \& Mokgethi, B.G., 2008, African theology/Black theology in South Africa: Looking back, moving on, University of South Africa, Pretoria.

Mpunzi, A., 1974, 'Black theology as liberation theology', in B. Moore (ed.), The challenge of Black theology, pp. 130-140, John Knox, Atlanta.

Mugambi, J.N.K., 1989, Jesus in African Christianity, Initiatives, Nairobi.

Mukendi, P., 2005, Théologie de libération africaine [African liberation theology], Mission MED, Kinshasa.

Ndjate, T., 1984, De la logique de l'existence négro-africaine à l'appel du mystère chrétien pour une exploitation théologique du concept Tetela [The logic of the Black African presence in the Christian mystery: Call for operation of the theological concept Tetela], Katholisch Theologische Fakultat, Tubingen.

Ntwasa, S. \& Moore, B., 1974, 'The concept of God in Black theology', in B. Moore (ed.), The challenge of Black theology, pp. 18-28, John Knox, Atlanta.

Simms, R., 2000, 'Black theology, a weapon in the struggle for freedom: A Gramscian analysis', Race E Society 2(2), 165-193.

Tutu, D., 1974, 'Black theology', Frontier 17, 73-76.

Villa-Vicencio, C., 1994, 'Doing theology in context: South African perspectives', in J.W. deGruchy \& C. Villa-Vicencio (eds.), Or God Talk Under Devils Peak, p. 259, Orbis, Maryknoll. 